\title{
Chapter 7 \\ From Hand-Counting to GIS: \\ Richardson in the Information Age
}

\author{
Kristian Skrede Gleditsch and Nils B. Weidmann
}

\begin{abstract}
Richardson made pioneering contributions to the study of geography and its influence on social and political dynamics. We use the research of Richardson as a point of departure to examine how Geographic Information Systems (GIS) technology and spatial data provide opportunities to answer old and new questions in conflict research. There is an enduring interest in how geographical features influence political interactions and outcomes and increasing attention to how key factors highlighted vary spatially both within countries and beyond national boundaries. We focus on key motivations for using spatially disaggregated data and show how such data can help advance core research questions, drawing on examples from the study of violent conflict.
\end{abstract}

\subsection{Introduction}

Lewis Fry Richardson collected an influential early database on 'deadly quarrels' and made prominent contributions to modelling interactions such as arms races using differential equations (Hess, 1995; Nicholson, 1999; Richardson, 1960a). Less well known is Richardson's pioneering work on geography, examining topics such as the relationship between borders and conflict, developing measures of territorial properties such as 'compactness', as well as a number of interesting observations on the political implications and origins of borders (Richardson, 1960b, 1961). For example, Richardson noted how administratively determined internal borders tended to look very different from 'natural' external borders. While

\footnotetext{
The original version of this chapter was revised: The name "Gregory D. Hess" has been corrected to "George D. Hess" in Reference list. The correction to this chapter is available at https://doi.org/10.1007/978-3-030-31589-4_12
}

This chapter is a shortened version of Gleditsch \& Weidmann (2012), with some revision and updating. Reprinted with permission. 
the latter tend to follow physical features such as rivers or mountain ranges, the former often take the form of straight lines clearly drawn directly on a map, usually without regard for natural features (see also Mandelbrot, 1967 on the scale effect of borders noted by Richardson). Richardson further noted that there were no instances of four independent states meeting in a single point, such as the Four Corners area of the United States. He attributed this to the role of warfare in shaping borders and the difficulty of maintaining border arrangements that would be difficult to defend militarily. The Caprivi Strip, a protruding part of northeastern Namibia, is sometimes held up as a contemporary counterexample to Richardson's observation. Namibia and Zimbabwe do not appear to be contiguous, even if both border the Zambezi river. Still, this strangely shaped area emerged from complex treaties between the UK and Germany, and has seen considerable conflict and contention, consistent with Richardson's core intuition.

Richardson had limited tools at his disposal when writing in the 1930s, and most of his geographical computations were done by hand. In this chapter, we review research picking up the gavel from Richardson, using the tools of the information age and advances in Geographic Information Systems (GIS). We show that spatial data can provide important new insights in conflict research, enhance theory-measure correspondence, and inform models of spatial variation and processes.

\subsection{The GIS Revolution in the Social Sciences}

Contemporary research often uses GIS to examine smaller and more fine-grained data. 'Spatial disaggregation' is often employed to move below the country-level and use local indicators to better approximate the specific actors and mechanisms of interest (Cederman \& Gleditsch, 2009). For example, researchers have focused on the conflict zones in civil wars and examining local correlates of violence. Moreover, GIS can help provide access to new information relevant to conflict processes such as the spatial concentration of ethnic groups or proximity to conflict. In addition, spatial datasets can be used to capture phenomena that are plausibly exogenous to social processes such as for example weather or terrain, which can be extremely useful for causal identification.

The term 'Geographic Information System' denotes a family of software tools that allow for the collection, visualization and analysis of spatial data. GIS analysis extends beyond creating maps, and a key promise lies in the ability to compute spatial indicators. Some computations operate on a single dataset (or 'layer') as input. For example, only one input layer of country borders is required to compute minimum distances between countries. More complex operations use the spatial co-occurrence of information contained in different datasets. For example, we can compute an indicator of terrain ruggedness by overlaying data on units with information about territorial elevation, and then examine it is relationship with conflict events.

Richardson's (1960b) dataset on 'deadly quarrels' contained much information but did not provide very previse spatial information. There has been a rapid growth 
in GIS use over the last decade, and many GIS datasets cover issues relevant to conflict researchers, with explicit spatial information. Furthermore, it is straightforward to collect new GIS data for spatial analysis. Spatial data can be represented either in a vector or a raster format. Vector formats are typically used for discrete spatial entities, while rasters represent a continuous variable over space. Our discussion here must be selective, and we refer to Gleditsch \& Weidmann (2012) and Ward \& Gleditsch (2018) for more detailed general overviews.

We focus on a worked example of measuring horizontal inequality across ethnic groups within countries, based on Cederman et al. (2011). There is a long research tradition on whether grievances generated by economic inequality increase conflict (Gurr, 1970). Earlier research found more political protest under higher inequality (Muller \& Seligson, 1987), but many studies of civil war find no clear relationship between measures of interpersonal income inequality and conflict (Collier \& Hoeffler, 2004). However, 'vertical' inequality between individuals is conceptually distinct from 'horizontal' inequalities that coincide with other salient cleavages such as ethnic divisions. Many argue that the latter is more likely to spur violent mobilization, given the important relationship between ethnic groups and opportunities for collective action (see Cederman et al., 2011; Stewart, 2008; Østby, 2008).

The first building block in our example is data on national boundaries. Our CShapes dataset provides historical country borders as vector polygons for the post-World War II period (Weidmann et al., 2010). Even if borders are not of primary interest, these data allow linking other variables of interest to spatial referents and create maps or spatial measures. In addition, the associated CShapes $\mathrm{R}$ package allows the user to compute derived measures from the country polygons, such as the minimum distance between countries (Weidmann \& Gleditsch, 2010).

GeoEPR (Wucherpfennig et al., 2011) is a spatial extension to the Ethnic Power Relations dataset (Wimmer et al., 2009), and provides a dynamic spatial coding of ethnic group settlement regions, with polygon 'lifespans'. GeoEPR makes it possible to rely on GIS techniques (in particular, overlays) to derive a variety of spatial and non-spatial indicators for ethnic groups.

The G-Econ data provides estimate of sub-national economic activity for 1-degree grid cells (Nordhaus, 2006). We can derive per capita and inequality measures for ethnic groups by overlying the G-Econ data with the GeoEPR settlement polygons and demographic information from the Gridded Population of the World, ${ }^{1}$ a raster with a resolution of 2.5 arc-minutes.

Figure 7.1 illustrates the construction of the measures for Yugoslavia. Overlaying the G-Econ data and the GeoEPR data gives us a measure of total economic activity by group settlement area. We can then consider group inequality by comparing per-capita wealth for each group with the national average, with values above 1 for relatively more affluent groups and values below 1 for poorer groups (Fig. 7.1, right). The ratios indicate that Albanians in Kosovo are on average poorer than the national average, while the Croats and the Slovenes are wealthier.

\footnotetext{
${ }^{1}$ http://sedac.ciesin.columbia.edu/data/collection/gpw-v4.
} 
Yugoslavia: GECON and GeoEPR (1990)

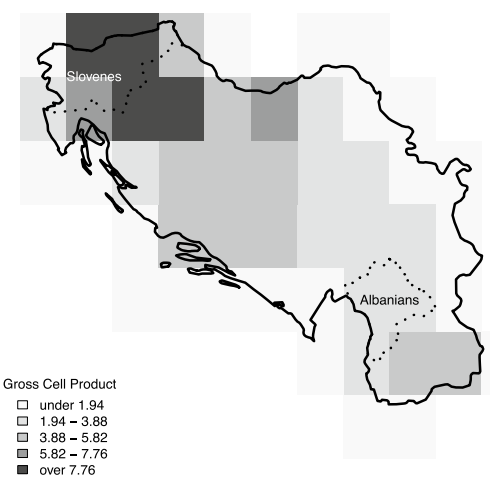

Yugoslavia

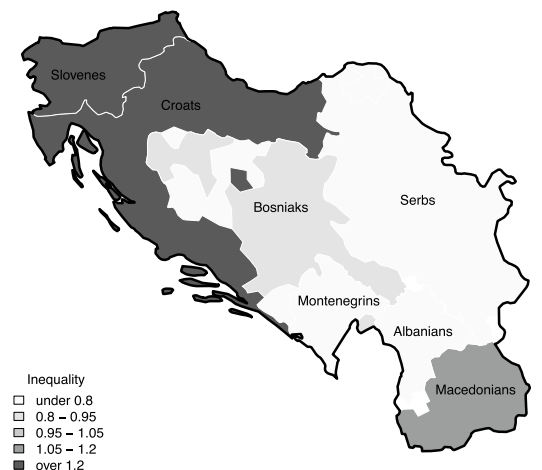

Fig. 7.1 Example for the computation of the group wealth indicator. The G-Econ dataset on economic performance is overlaid with the group settlement regions from Geo-EPR (left). Aggregating the (partial) G-Econ cell values by group results in wealth estimates at the group level (shown as proportions of the national average, right). Source The authors

Cederman et al. (2011) use these ratios in a global analysis and find that large inequalities along ethnic lines are associated with a higher risk of ethnic conflict, both for relatively disadvantaged and privileged groups.

Cederman et al. (2011) use information reflecting whether actors in armed conflict as described by Gleditsch et al. (2002) are linked to ethnic groups, but the conflict data are not actually spatial. We now have a host of spatial datasets on political violence. In an early attempt to spatially reference civil war, Buhaug \& Gates (2002) coded a 'conflict zone' based on the smallest circle surrounding all violent events in a given country and year and examined how location and scope varied by geographical characteristics and country attributes (see also Hallberg, 2012). Other data sources attempt to provide precise information on the individual events that make up a 'war' or conflict episode, tagged each event with temporal and spatial coordinates in a point vector representation. The Armed Conflict Location and Event Dataset ACLED (Raleigh et al., 2010, www.acleddata.com) as well as the Georeferenced Event Data (GED) of the Uppsala Conflict Data Project (Sundberg \& Melander, 2013) provide incident level data for civil wars and non-state actor conflict. For interstate conflict, the MIDLOC dataset (Braithwaite, 2010) reports the onset of each episode in the Militarized Interstate Disputes dataset. The Social Conflict Analysis Database (SCAD, Salehyan et al., 2012) provides spatial coordinates for non-violent and less organized violent events, including riots, strikes, and protests.

It is increasingly popular to use GIS datasets for information on geographic or environmental characteristics that can help support casual inference. Concern over the potential endogeneity of various economic and political explanatory factors have led researchers to look to geographic or environmental characteristics as potentially exogenous sources of variation or 'deep' determinants. For example, 
Miguel et al. (2004) use rainfall data as plausible exogenous shocks in economies dominated by rainfed agriculture to improve causal identification of the effects of economic growth on conflict. Michalopoulos (2012) argues that soil quality and elevation provide exogenous sources of ethnic diversity, as higher regional variation should reduce migration and lead to a higher number of ethnic groups. Many environmental variables can be measured using satellite imagery. The GTOPO30 dataset is a global raster data on territorial elevation, measured at the level of grid cells with a resolution of 30 arc-seconds. ${ }^{2}$ Estimates of rainfall and related variables are provided in raster formats by the Global Precipitation Climatology Project, available at https://rda.ucar.edu/datasets/ds728.3/.

Disaggregated spatial data come in different resolutions and combining different data sources usually require scaling to some common resolution. The PRIO-GRID project (Tollefsen et al., 2012) provides a standardized grid structure that integrates different data sources to a common set of geographical cells with a resolution of 0.5 decimal degrees (roughly $50 \mathrm{~km}$ at the equator). Buhaug et al. (2011) provide a grid cell analysis of local economic characteristics and the initial onset event in a conflict, controlling for a host of social and political factors believed to influence the risk of conflict.

Rather than relying on existing spatial datasets, researchers may create new spatial datasets by either recording spatial coordinates when data are collected, or appending spatial information to existing, non-spatial data, a step that is usually called 'geo-referencing'. Spatial coordinates for observations can be derived by the Global Positioning System (GPS), where a GPS receiver with the help of satellites can determine geographic position with a high level of accuracy. Surveys often record the geographic position of a respondent or an interview, which allows linking these to other GIS layers. The Demographic and Health Surveys project, for example, conducting surveys on various living standards and health related outcomes for households, routinely attaches GPS coordinates (www.measuredhs.com). For example, Hegre et al. (2009) use DHS data to approximate geographical variation in poverty by grids in Liberia.

Existing, non-spatial datasets can be made GIS-compatible in different ways. Event datasets from news reports usually obtain spatial coordinates by converting place names into geographic coordinates. The location of the village or city mentioned in media reports can be found with the help of gazetteers, a list of place names and their spatial coordinates. Useful gazetteers include the Falling Rain database (www.fallingrain.com/world/index.html), or the GEOnet Names Server at the NGA (http://geonames.nga.mil/gns/html/). Since the spelling of place names often is not standardized, the JRC Fuzzy Gazetteer (http://isodp.hofuniversity.de/ fuzzyg/query/) is particularly convenient, since it retrieves place names even if the spelling does not match perfectly.

Alternatively, GIS databases can be created by converting existing maps into GIS-compatible formats. After scanning maps and aligning the map correctly with

\footnotetext{
${ }^{2}$ https://eros.usgs.gov/\#/Find_Data/Products\%20and_Data_Available/gtopo30_info.
} 
the spatial reference system used by the GIS, the spatial features of interest can be extracted manually or by applying a feature recognition algorithm (see Longley et al., 2010). Vanzo (1999), for example, geocodes historical maps reflecting boundary changes to examine to what extent post-conflict borders reflect a tendency towards greater territorial compactness.

\subsection{GIS and Spatial Data Analysis}

Our first example of GIS in analysis considers how information on the location of violence can help inform research on the causes and consequences of conflict. Much research has considered 'civil war' as a dichotomous outcome, where states are either 'at war' or not over some specific period. However, civil wars rarely engulf entire countries and come in many different degrees, both in terms of the severity and geographical scope of fighting. The Conflict Sites dataset expands the Uppsala Armed Conflict Data to a geographical representation of the zone where violence takes place, using a polygon representation. Figure 7.2 displays two important examples of variation in the distribution in civil wars. For example, the Chechen War in 1995 (left panel) is confined to a relatively small and peripheral part of the territory of Russia, and clearly does not extend to the entire country. The conflict zone is small and unlikely to influence national figures, and national level data are unlikely to reflect the local impact of the conflict in the region. Conversely, the Democratic Republic of Congo in 2007 (right panel) experiences two distinct civil wars that take place in completely different parts of the country, with the National Congress for the Defence of the People (CNDP, a Tutsi dominated organization) in the East, and the Bundu Dia Kongo, which claims to represent the Kongo people, in the West. Treating the country at large as 'at war' distracts our attention from the distinct actors and conflictual interactions taking place.
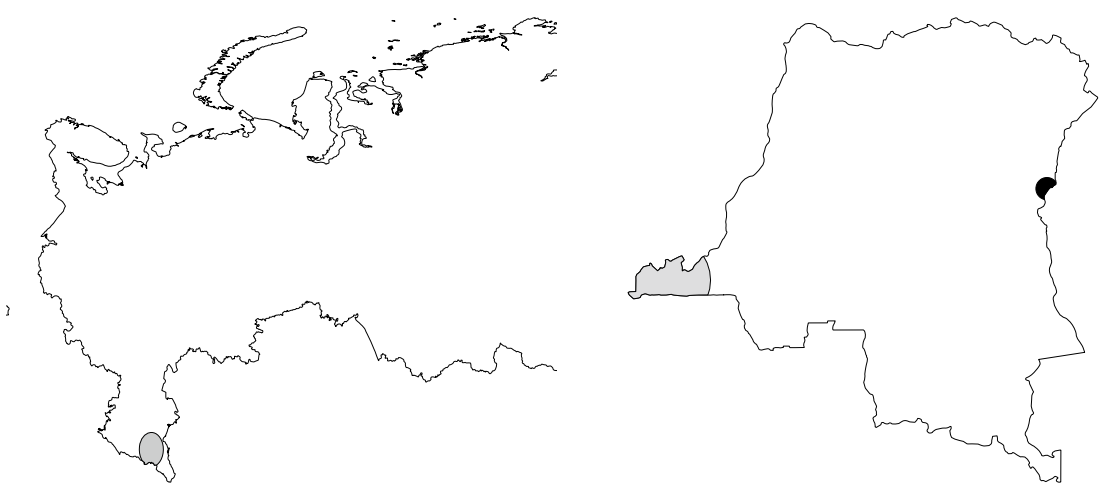

Fig. 7.2 Conflict polygons for the Chechen War in Russia in 1995 (left), and the 2007 civil wars in the Democratic Republic of Congo (right). Source The authors 
GIS provide opportunities for more systematic analyses of how spatially varying features influence conflict. If politics are local, then the causes of the conflict are more likely to reflected in the characteristics of the areas where they occur rather than features of state at large. By construction, many conventional country-level measures such as Gross Domestic Product per capita or ethnic fractionalization are averages that reflect population density and will not reflect variation within countries. Buhaug \& Lujala (2005) compare conflict zones to other areas within the same country without conflict using GIS data, and demonstrate that conflict zones tend to be very different from other areas of a country. Since civil wars tend to be fought by small groups, often in thinly populated peripheral areas, the risk of conflict may be better reflected by 'worst case' indicators, or measures of the geographical areas most likely to see conflict, rather than population weighted measures (Buhaug et al., 2014). More generally, researchers should think carefully about correspondence between actual measures and the underlying theoretical concepts. Just because a particular measure is available or is used in existing research it does not necessarily follow that it is a suitable indicator for testing a particular argument.

Buhaug \& Gates (2002) examine a number of hypotheses on possible factors that may account for variation in the size or geographical scope of conflict zones. They find strong evidence that the presence of natural resources within conflicts and their overall duration influence the geographical scope of conflicts, and their results suggest a possible endogenous relationship between the peripheral location of conflict and its geographical scope.

The consequences of conflict are likely to be proportional to their magnitude. Although civil wars can be shown to have a negative impact on social and economic development, it seems unreasonable to expect that conflicts with a limited geographical scope would have identical consequences to large conflicts with broad geographical reach. As a supplement to national level studies (e.g., Bozzoli et al., 2010), many studies that look at the impact of conflict at the household or individual level using survey data (Verwimp et al., 2009).

Beyond static features, spatial data can also be used to analyze the dynamics of change over time, such as the diffusion of conflict. Many important mechanisms can create spatial dependence between actors or locations and increase the risk of conflict. More generally, if ongoing conflict in one country can affect the risk of conflict in other states, the individual conflict outbreaks are not independent as the outcomes are shaped by events and outcomes in other, connected observations.

Much of the research on civil war has adopted a 'closed polity' approach, assuming that the relevant causes of internal conflicts must be found within the boundaries of the country experiencing conflict (Gleditsch, 2007). However, there are strong theoretical reasons why the risk of conflict may be shaped by events and features in other states, especially neighboring countries. For example, many conflicts involve demands for autonomy or independence by ethnic communities, who often reside in multiple countries (Cederman et al., 2009; Lake \& Rothchild, 1998). The decision to contest the state militarily can be influenced by experiences of the group in another state, or the ability to rely on financial or military support from kin in another state. An ongoing civil war in a neighboring country can increase the 
availability of arms and recruits and make it relatively less costly to mobilize insurgencies (Lischer, 2005; Salehyan \& Gleditsch, 2006). Hostile relations between states can give governments incentives to support insurgencies in a neighboring state to undermine their rival (Davis \& Moore, 1997; Salehyan et al., 2011).

GIS data can used to examine whether conflict affected areas cluster geographically and how they evolve over time. The Great Lakes Region of Africa in the 1990s is often cited as an example of a cluster of interdependent civil wars (Prunier, 2008; McNulty, 1999). Figure 7.3 displays the Conflict Sites polygons for the years 1991 to 1999. The civil war in Rwanda erupted when the Rwandan Patriotic Front (RPF) invaded from Uganda in 1991, where a Tutsi refugee population of about 200,000 individuals had organized militarily, with assistance from Ugandan authorities and partial integration of rebel forces in the regular army.
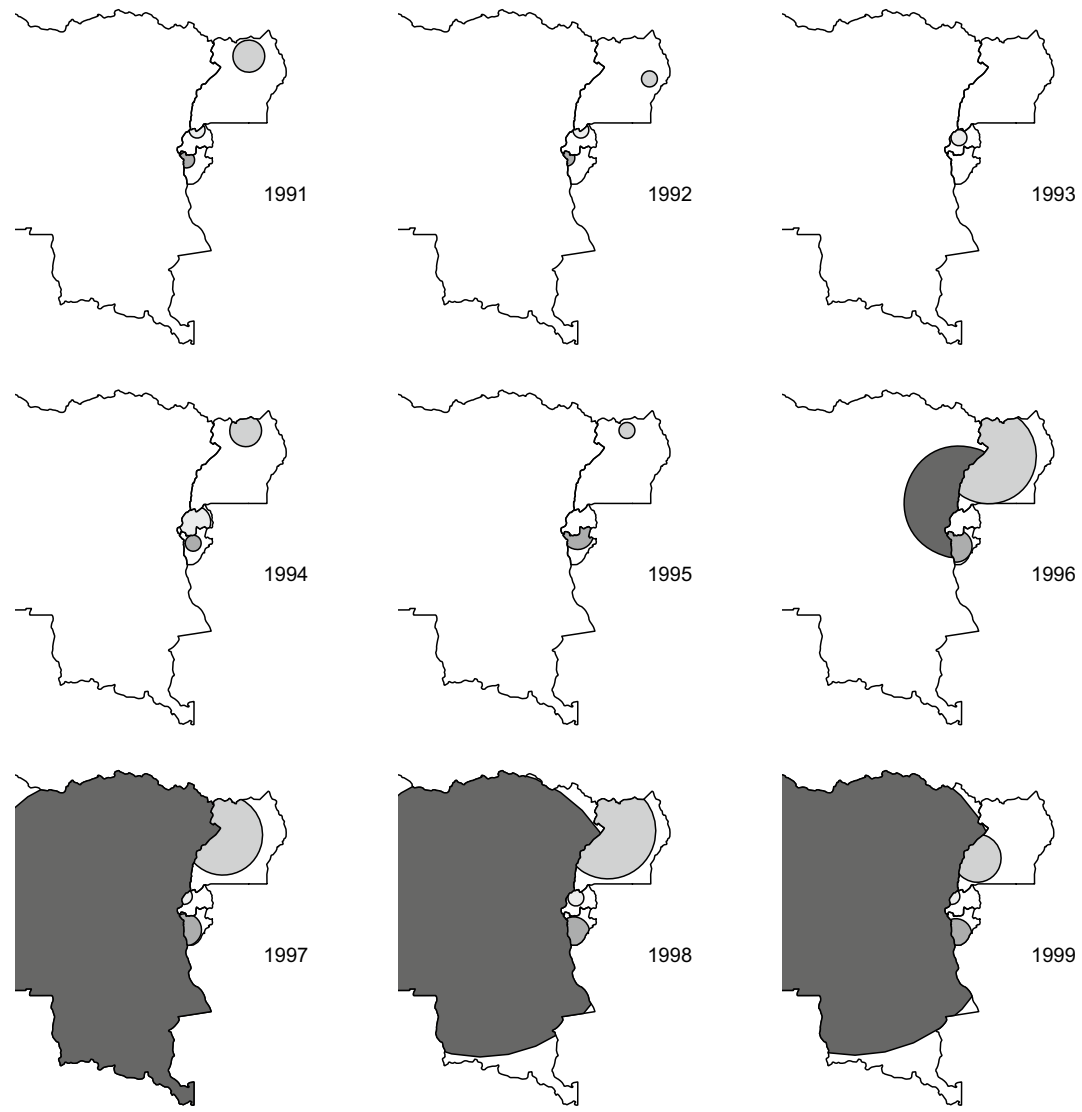

Fig. 7.3 Conflict polygons in the Great Lakes Region of Africa, 1991-99. Source The authors 
The conflict polygon in Rwanda is clearly located on the border, reflecting the important ties to Uganda, as the RPF on occasion retreated into Uganda to regroup and rearm during the initial period.

The maps for the subsequent years reflect the escalation to encompass the whole country around the Rwandan genocide in 1994 and the eventual RPF victory. The Rwandan civil war generated a major Hutu refugee crisis in neighboring countries, in particular Zaire, where the refugee camps provided a fertile environment for a Hutu insurgent movement, the Rassemblement Démocratique pour le Rwanda. In response, the Kagame government in Rwanda supported an insurgent group in Zaire, the Alliance of Democratic Forces for the Liberation of Congo (AFDL) led by Kabila. This is reflected in the conflict polygon in Eastern Zaire in 1996, again clearly on the border with Rwanda. The 1997 maps show the subsequent escalation, where the AFDL overthrows Mobutu in 1997 and declares a new Democratic Republic of the Congo (DRC). The maps for the subsequent years demonstrate how peace has remained elusive in the region, and possibly may have fueled an escalation of the civil war in Uganda.

These spatial representations are in line with Richardson's emphasis on borders as an opportunity for interaction and the diffusion of conflict (Richardson, 1960b, 1961; see also Siverson \& Starr, 1991). Although this is just a single case, many global studies find considerable support for the importance of spatial proximity in conflict diffusion (Bosker \& de Ree, 2014; Gleditsch, 2007; Ward \& Gleditsch, 2002). Hegre \& Sambanis (2006) report neighboring conflict as one of the key features with a robust positive influence on the risk of civil war in their sensitivity analysis. Other researchers have estimated the effects of specific mechanisms or transnational linkages, including transborder ethnic kin (Bosker \& de Ree, 2014; Cederman et al., 2009), or refugee flows (Salehyan \& Gleditsch, 2006). More recent studies have looked at diffusion within individual conflicts. Schutte \& Weidmann (2011) distinguish between two types of diffusion, relocation and escalation, each of which is the result of a particular type of warfare. They find that civil wars primarily exhibit escalation diffusion as a result of irregular warfare without conventional front lines. Weidmann \& Ward (2010) consider the spatial and temporal diffusion for conflict events in Bosnia, demonstrating that violence is likely to recur over time and spread spatially, and showing that taking advantage of this information can substantial improve the ability to forecast conflict.

\subsection{Conclusion}

We started by arguing that GIS and the increasing availability of spatial data provide many opportunities for advancing research on the spatial features of conflict and political interactions highlighted in the pioneering research by Richardson. There is an interesting analogy here to Richardson's (1922) work on weather forecasting, which proposed a system based on solving differential equations that was not computationally feasible at the time. Subsequent advances in computing, 
however, have vindicated Richardson's ideas (Lynch, 2006). The first modern computer ENIAC generated a weather forecast in 1950, and similar models are today used extensively for weather forecasting and modeling climate change. Of course, meteorological processes are different from social interactions that often involve strategic behavior and responses, but spatial variation and features can be incorporated in many strategic formal models (e.g., Fujita et al., 2001; Alesina \& Spolaore, 2003) or computational models (e.g., Turchin, 2003; Epstein, 2007).

Our overview provides strong support for the claim that GIS and spatial data has helped advance research on spatial features and political interactions and outcomes in the spirit of Richardson's initial efforts. Spatial data have helped facilitate new approaches to the study of inequality and conflict, which at least to some provide a vindication of the role of grievances in civil war often dismissed in other research. We have learned important things about the risks of conflict diffusion, as well as of specific conditions where conflicts are more or less likely to generate instability in other countries. Although much work remains to be done, we believe that Richardson would have been very pleased to see the results of existing research using GIS and spatial data.

The spatial perspective is not just a question of tools and techniques, but also helps foster a substantively novel theoretical approach for understanding political events and outcomes. Whereas much research often takes states as predetermined units with fixed boundaries, Richardson's work on borders alerts us to the endogenous nature of borders, and how present-day borders reflect historical and political processes that have generated and preserved borders (Alesina et al., 2011; Englebert et al., 2002). Whereas much comparative research traditionally may have treated individual countries as independent units, interdependence is an essential characteristic of a globalizing world.

\section{References}

Alesina, Alberto \& Enrico Spolaore (2003) The Size of Nations. Cambridge, MA: MIT Press. Alesina, Alberto; William Easterly \& Janina Matuszeski (2011) Artificial states. Journal of the European Economic Association 9(2): 246-277.

Bosker, Maarten \& Joppe de Ree (2014) Ethnicity and the spread of civil war. Journal of Development Economics 108: 206-221.

Bozzoli, Carlos; Tilman Brück \& Simon Sottsas (2010) A survey of the global economic costs of conflict. Defence and Peace Economics 21(2): 165-176.

Braithwaite, Alex (2010) MIDLOC: Introducing the Militarized Interstate Dispute Location dataset. Journal of Peace Research 47(1): 91-98.

Buhaug, Halvard \& Scott Gates (2002) The geography of civil war. Journal of Peace Research 39 (4): 417-433.

Buhaug, Halvard \& Päivi Lujala (2005) Accounting for scale: Measuring geography in quantitative studies of civil war. Political Geography 24(4): 399-418.

Buhaug, Halvard; Kristian Skrede Gleditsch, Helge Holtermann, Gudrun Østby \& Andreas Forø Tollefsen (2011) It's the local economy, stupid! Geographic wealth dispersion and conflict outbreak location. Journal of Conflict Resolution 55(5): 814-884. 
Buhaug, Halvard; Lars-Erik Cederman \& Kristian Skrede Gleditsch (2014) Square pegs in round holes: Grievances, inequalities, and civil war. International Studies Quarterly 58(2): 418-431.

Cederman, Lars Erik \& Kristian Skrede Gleditsch (2009) Special Issue on 'Disaggregating civil war'. Journal of Conflict Resolution 53(4): 487-495.

Cederman, Lars-Erik; Luc Girardin \& Kristian Skrede Gleditsch (2009) Ethno-nationalist triads: Assessing the influence of kin groups on civil wars. World Politics 61(3): 403-437.

Cederman, Lars-Erik; Nils B Weidmann \& Kristian Skrede Gleditsch (2011) Horizontal inequalities and ethno-nationalist civil war: A global comparison. American Political Science Review 105(2): 478-495.

Collier, Paul \& Anke Hoeffler (2004) Greed and grievance in civil war. Oxford Economic Papers 56: 663-595.

Davis, David R \& Will H Moore (1997) Ethnicity matters: Transnational ethnic alliances and foreign policy behavior. International Studies Quarterly 41(1): 171-184.

Englebert, Pierre; Stacey Tarango \& Matthew Carter (2002) Dismemberment and suffocation: A contribution to the debate on African boundaries. Comparative Political Studies 35(10): 1093-1118.

Epstein, Joshua M (ed) (2007) Generative Social Science: Studies in Agent-Based Computational Modeling. Princeton, NJ: Princeton University Press.

Fujita, Masahisa; Paul Krugman \& Anthony J Venables (2001) The Spatial Economy: Cities, Regions, and International Trade. Cambridge, MA: MIT press.

Gleditsch, Kristian Skrede (2007) Transnational dimensions of civil war. Journal of Peace Research 44(3): 293-309.

Gleditsch, Kristian Skrede \& Nils B Weidmann (2012) Richardson in the information age: Geographic information systems and spatial data in international studies. Annual Review of Political Science 15: 461-481. Revised version in German: Geodaten und deren Analyse in der Politikwissenschaft. In: Claudius Wagemann, Achim Goerres \& Markus Siewert (eds) (2018) Handbuch Methoden der Politikwissenschaft. Frankfurt: Springer, https://doi.org/10.1007/9783-658-16937-4_23-1.

Gleditsch, Nils Petter; Peter Wallensteen, Mikael Eriksson, Margareta Sollenberg \& Håvard Strand (2002) Armed conflict 1946-2001: A new dataset. Journal of Peace Research 39(5): 615-637.

Gurr, Ted R (1970) Why Men Rebel. Princeton, NJ: Princeton University Press.

Hallberg, Johan Dittrich (2012) PRIO Conflict Sites 1989-2008: A geo-referenced dataset on armed conflict. Conflict Management and Peace Science 29(2): 219-32.

Hegre, Håvard \& Nicholas Sambanis (2006) A sensitivity analysis of the empirical literature on civil war onset. Journal of Conflict Resolution 50(4): 508-535.

Hegre, Håvard; Gudrun Østby \& Clionadh Raleigh (2009) Poverty and civil war events: A disaggregated study of Liberia. Journal of Conflict Resolution 53(4): 598-623.

Hess, George D (1995) An introduction to Lewis Fry Richardson and his mathematical theory of war \& peace. Conflict Management and Peace Science 14(1): 77-113.

Lake, David A \& Donald Rothchild (eds) (1998) The International Spread of Ethnic Conflict: Fear, Diffusion, and Escalation. Princeton, NJ: Princeton University Press.

Lischer, Sarah Kenyon (2005) Dangerous Sanctuaries: Refugee Camps, Civil War, and the Dilemmas of Humanitarian Aid. Cornell, NY: Cornell University Press.

Longley, Paul A; Michael F Goodchild, David J Maguire \& David W Rhind (2010) Geographic Information Systems and Science. Chichester: Wiley.

Lynch, Peter (2006) The Emergence of Numerical Weather Prediction: Richardson's Dream. Cambridge: Cambridge University Press.

Mandelbrot, Benoit (1967) How long is the coast of Britain? Statistical self-similarity and fractional dimension. Science 156(3775): 636-638.

McNulty, Mel (1999) The collapse of Zaire: Implosion, revolution, or external sabotage? Journal of Modern African Studies 39(1): 53-82.

Michalopoulos, Stelios (2012) The origins of ethnolinguistic diversity. American Economic Review 102(4): 1508-1039. 
Miguel, Edward; Shanker Satyanath \& Ernest Sergenti (2004) Economic shocks and civil conflict: An instrumental variables approach. Journal of Political Economy 112(4): 725-753.

Muller, Edward N \& Mitchell A Seligson (1987) Inequality and insurgency. American Political Science Review 87(2): 425-451.

Nicholson, Michael (1999) Lewis Fry Richardson and the study of the causes of war. British Journal of Political Science 29(3): 541-563.

Nordhaus, William D (2006) Geography and macroeconomics: New data and new findings. Proceedings of the National Academy of Sciences USA 103(10): 3510-3517.

Østby, Gudrun (2008) Polarization, horizontal inequalities and violent civil conflict. Journal of Peace Research 45(2): 143-162.

Prunier, Gerard (2008) Africa's World War: Congo, the Rwandan Genocide, and the Making of a Continental Catastrophe. Oxford: Oxford University Press.

Raleigh, Clionadh; Andrew Linke, Håvard Hegre \& Joakim Karlsen (2010) Introducing ACLED: An armed conflict location and event dataset. Journal of Peace Research 47(5): 651-660.

Richardson, Lewis F (1922) Weather Prediction by Numerical Process. Cambridge: Cambridge University Press.

Richardson, Lewis F (1960a) Arms and Insecurity. Pittsburgh, PA: Boxwood.

Richardson, Lewis F (1960b) Statistics of Deadly Quarrels. Pittsburgh, PA: Boxwood.

Richardson, Lewis F (1961) The problem of contiguity: An appendix to Statistics of Deadly Quarrels. General Systems Yearbook 6: 140-187. Reprinted in: Oliver M Ashford, H Charnock, PG Drazin, Julian CR Hunt, Paul Smoker \& Ian Sutherland (eds) Collected Papers of Lewis Fry Richardson, 2 Quantitative Psychology and Studies of Conflict. Cambridge: Cambridge University Press, 577-627.

Salehyan, Idean \& Kristian Skrede Gleditsch (2006) Refugee flows and the spread of civil war. International Organization 60(2): 335-366.

Salehyan, Idean; Kristian Skrede Gleditsch \& David Cunningham (2011) Explaining external support for insurgent groups. International Organization 65(4): 709-744.

Salehyan, Idean; Cullen S Hendrix, Jesse Hamner, Christina Case, Christopher Linebarger, Emily Stull \& Jennifer Williams (2012) Social conflict in Africa: A new database. International Interactions 38(4): 503-511.

Schutte, Sebastian \& Nils B Weidmann (2011) Diffusion patterns of violence in civil wars. Political Geography 30(3): 143-152.

Siverson, Randolph M \& Harvey Starr (1991) The Diffusion of War: A Study in Opportunity and Willingness. Ann Arbor, MI: University of Michigan Press.

Stewart, Frances (ed) (2008) Horizontal Inequalities and Conflict: Understanding Group Violence in Multiethnic Societies. Houndmills: Palgrave Macmillan.

Sundberg, Ralph \& Erik Melander (2013) Introducing the UCDP Georeferenced Event Dataset. Journal of Peace Research 50(4): 523-532.

Tollefsen, Andreas Forø; Håvard Strand \& Halvard Buhaug (2012) PRIO-GRID: A unified spatial data structure. Journal of Peace Research 49(2): 363-374.

Turchin, Peter (2003) Historical Dynamics: Why States Rise and Fall. Princeton, NJ: Princeton University Press.

Vanzo, John P (1999) Border configuration and conflict: Geographical compactness as a territorial ambition of states. In: Paul Diehl (ed) A Road Map to War: Territorial Dimensions of International Conflict. Nashville, TN: Vanderbilt University Press, 73-112.

Verwimp, Philip; Patricia Justino \& Tilman Brück (2009) The analysis of conflict: A micro-level perspective. Journal of Peace Research 46(3): 307-314.

Ward, Michael D \& Kristian Skrede Gleditsch (2002) Location, location, location: An MCMC approach to modeling the spatial context of war and peace. Political Analysis 10(2): 244-260.

Ward, Michael D \& Kristian Skrede Gleditsch (2018) Spatial Regression Models. Second edition. Thousand Oaks, CA: Sage.

Weidmann, Nils B \& Kristian Skrede Gleditsch (2010) Mapping and measuring country shapes: The Cshapes package. $R$ Journal 2(1), online at http://journal.r-project.org/archive/2010-1/. 
Weidmann, Nils B \& Michael D Ward (2010) Predicting conflict in space and time. Journal of Conflict Resolution 54(6): 883-901.

Weidmann, Nils B; Doreen Kuse \& Kristian Skrede Gleditsch (2010) The geography of the international system: The CShapes dataset. International Interactions 36(1): 86-106.

Wimmer, Andreas; Lars-Erik Cederman \& Brian Min (2009) Ethnic politics and armed conflict: A configurational analysis of a new global dataset. American Sociological Review 74(2): 316-337.

Wucherpfennig, Julian; Nils B Weidmann, Luc Girardin, Lars-Erik Cederman \& Andreas Wimmer (2011) Politically relevant ethnic groups across space and time: Introducing the GeoEPR dataset. Conflict Management and Peace Science 28(5): 423-437.

Kristian Skrede Gleditsch, b. 1971, Ph.D. in Political Science (University of Colorado, Boulder, 1999); Regius Professor, Department of Government, University of Essex (2005/2018- ); Research Associate, Peace Research Institute Oslo (2003- ); current research interests: violent and nonviolent conflict, democratization, and political violence, ksg@essex.ac.uk

Nils B Weidmann, b. 1976, Ph.D. in Political Science (ETH Zurich, 2009); Professor of Political Science, University of Konstanz, Germany (2012- ) and head of the Communication, Networks and Contention research group; research interests: violent and nonviolent conflict, with a particular focus on the impact of communication and information technology, nils.weidmann@uni-konstanz.de

Open Access This chapter is licensed under the terms of the Creative Commons Attribution 4.0 International License (http://creativecommons.org/licenses/by/4.0/), which permits use, sharing, adaptation, distribution and reproduction in any medium or format, as long as you give appropriate credit to the original author(s) and the source, provide a link to the Creative Commons license and indicate if changes were made.

The images or other third party material in this chapter are included in the chapter's Creative Commons license, unless indicated otherwise in a credit line to the material. If material is not included in the chapter's Creative Commons license and your intended use is not permitted by statutory regulation or exceeds the permitted use, you will need to obtain permission directly from the copyright holder. 